\title{
New Strategies for Intramolecular Annulations: Intramolecular Additions of Silyloxycyclopropane-Derived Anions; Application to \\ Hydrindenone Syntheses
}

\author{
J.P. Marino ${ }^{* \mathrm{a}}$, Peter J. Stengel ${ }^{\mathrm{a}}$, Fabio Simonelli ${ }^{\mathrm{b}}$, and \\ J. Tércio B. Ferreira ${ }^{\mathrm{c} \#}$ \\ ${ }^{a}$ Department of Chemistry, The University of Michigan, Ann Arbor, Michigan 48109 \\ ${ }^{\mathrm{b}}$ Departamento de Química, Universidade Federal do Paraná, Brazil \\ ${ }^{\mathrm{c}}$ Departamento de Química, Universidade Federal de São Carlos, C.P. 676,
}

13560 São Carlos - SP, Brazil

Received: August 10, 1998

\begin{abstract}
Como uma extensão de nosso trabalho em anelações intramoleculares via anions derivados de sililoxiciclopropanos, investigamos a química dos sistemas ciclopentilciclopropanos 6-9, em um esforco visando a preparação de hidrindenonas estereoespecificamente funcionalizadas. As ciclizações intramoleculares de anions derivados do ciclopropano foram menos estereosseletivas e mais complicadas do que aquelas com o corresponente sitema cicloexila. Entretanto, rendimentos modestos de hidrindenonas, tais como $\mathbf{2 0}$ e $\mathbf{2 1}$, foram obtidos, assim como vários produtos derivados a partir de um deslocamento prototrópico que gerou enolatos de ciclopentanona. Estes últimos produtos possuem os sistemas 5,5-pentalenônicos 22 e 23.
\end{abstract}

As an extension to our work on intramolecular annulations via silyloxycyclopropane derived anions, we have investigated the chemistry of cyclopentyl cyclopropane systems, 6-9, in an effort to prepare stereospecifically functionalized hydrindenones. The intramolecular closures of the cyclopropane-derived anions were less stereoselective and more complicated than the corresponding cyclohexyl systems. Nevertheless, modest yields of isomeric hydrinenones such as $\mathbf{2 0}$ and $\mathbf{2 1}$ were obtained as well as several products derived from a prototropic shift to form the cyclopentanone enolates. These latter products possessed the 5,5-pentalenone systems, 22 and 23.

Keywords: hydrindenone syntheses, silyloxycyclopropane-derived anions

\section{Introduction}

For some time, synthetic chemists have sought efficient and stereospecific methods for carbocyclic annulations. Recently, we described a highly stereoselective annulative process which showcased the fluoride induced desilylation of a 2-(triethylsilyloxy)-1-carboethoxycyclopropane, resulting in an intramolecular conjugate addition of a $\gamma$-oxo$\alpha$-ester enolate onto a tethered vinyl sulfone ${ }^{1}$. In our initial report, fluoride induced cleavage of silyloxycyclopropane $\mathbf{1}$, obtained in three steps from cyclohexenone, resulted in the formation of the trans-fused decalenone $\mathbf{2}$ in high yield

\# This work is dedicated to the memory of Professor José Tércio Barbosa Ferreira who passed away in July, 1997. and in a completely stereoselective manner (Scheme 1). Ultimately, this protocol resulted in the efficient synthesis of a known octahydronaphthalene synthon 3 for dihdrocompactin.

The remarkable stereoselectivity of the intramolecular cyclization is presumably controlled by the cis-double bond of the sulfone diene side chain, which provides for a preferred approach of the enolate to the geometically accessible vinyl sulfone double bond.

Due to the high stereoselectivity achieved and the substitution pattern observed about the six-membered ring resulting from the annulation, we envisioned that our an- 


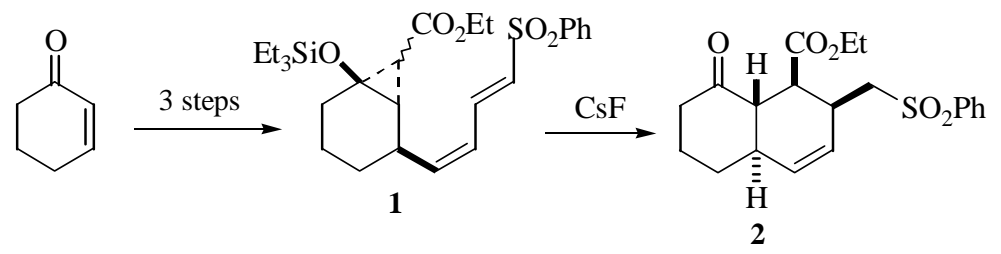

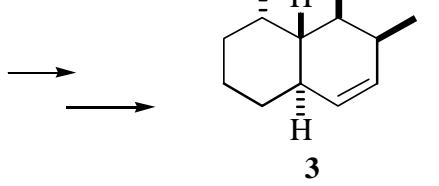

nulative process would be ideally suited for the synthesis of hydrindenone natural products, such as pulo'upone ${ }^{2} \mathbf{4}$ and the ionophore anitbiotic X-14547A 5 (Scheme 2).

We would now like to report our results on the extension of this annulative process toward the synthesis of hydrindenone systems.

\section{Results and Discussion}

In order to examine the scope and limitations of the cyclization reaction for the synthesis of hydrindenone systems, we chose to examine the cyclizations of four silyloxycyclopropanes $(\mathbf{6}, \mathbf{7}, \mathbf{8}, \mathbf{9})$ upon desilylation with cesium fluoride in acetonitrile (Scheme 3 ). We elected to incorporate a methyl sulfone into the side chain, as a related study performed in our group ${ }^{4}$, demonstrated that the methyl sulfone significantly improved cyclization. We also chose to study the cyclizations of compounds $\mathbf{8}$ and $\mathbf{9}$, which

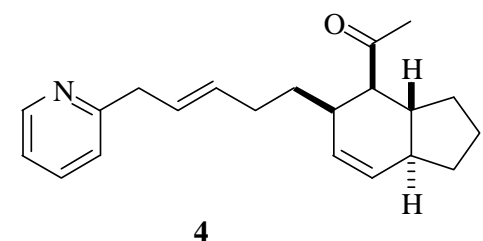

Pulo'upone contain a methyl substituent at carbon 5 and would allow for the synthesis of hydrindenones containing an angular methyl group.

The syntheses of the requisite silyloxycyclopropanes are summarized in Scheme 4. Addition of the cis-tri-nbutylstannylvinyl cuprate ${ }^{5}$ to cyclopentenone 10 at $-78{ }^{\circ} \mathrm{C}$, followed by trapping the resulting ketone enolate with triethylsilyl chloride at $-78{ }^{\circ} \mathrm{C}$, provided an $85 \%$ yield of the vinyl stannane 11. Under similar conditions, the addition of the stannylvinyl cuprate to 2-methyl-2-cyclopenten1-one 12 proceeded in low yields. However, high yields of the addition product $\mathbf{1 3}$ were obtained when the reaction mixture was warmed to $-20{ }^{\circ} \mathrm{C}$ prior to trapping the ketone enolate with triethylsilyl chloride at $-78^{\circ} \mathrm{C}$. The attachment of the vinyl sulfone unit was efficiently achieved by a Stille reaction ${ }^{6}$ involving trans-2-tosylvinylphenyl sulfone $\mathbf{1 4}$ or trans-2-tosylvinylmethyl sulfone ${ }^{7} \mathbf{1 5}$ and $\mathrm{PdCl}_{2}\left(\mathrm{PPh}_{3}\right)_{2}$ in

Scheme 2 .

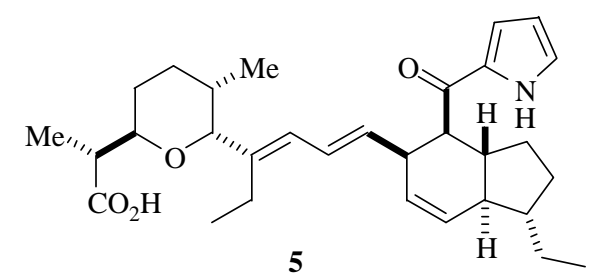

Ionophore Antibiotic X-14547A
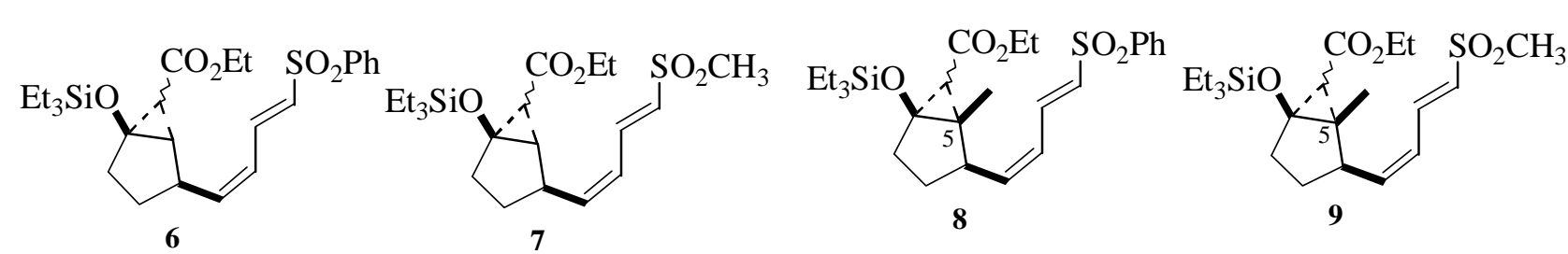

Scheme 3. 
THF at $65{ }^{\circ} \mathrm{C}$. The resulting sulfone dienes 16-19 were obtained routinely in high yield. Cyclopropanation of 1619 was accomplished by the addition of a benzene solution of ethyl diazoacetate to a suspension of ( $N$-benzylsalicylaldiminato)copper(II) catalyst $^{8}$ in the silyl enol ether at $70{ }^{\circ} \mathrm{C}$. The desired silyloxycyclopropanes 6-9 were obtained as a mixture of isomers at the carboxylate center in yields of $75 \%-85 \%$.

With the silyloxycyclopropanes 6, 7, 8 and 9 in hand, we completed this study by subjecting these compounds to the fluoride induced cyclization. We also examined the effects of varying the equivalents of cesium fluoride, in order to hopefully gain further insight into the role of the fluoride source during the cyclization. The cyclization reactions were performed with both one and five equivalents of anhydrous cesium fluoride in dry acetonitrile at $65^{\circ} \mathrm{C}$. When one equivalent of cesium fluoride was used, the reactions were followed by ${ }^{1} \mathrm{H}-\mathrm{NMR}$ analysis, in order to follow the progress of the reaction. An aliquot of the reaction mixture was removed at regular intervals throughout the reaction, quenched with saturated ammonium chloride, and extracted with ethyl acetate. After drying over anhydrous magnesium sulfate and concentration, the crude reaction mixtures were analyzed by ${ }^{1} \mathrm{H}-\mathrm{NMR}$. When the reactions were complete, the ratios of the products in the crude reaction mixtures were calculated from ${ }^{1} \mathrm{H}-\mathrm{NMR}$ integrations, as analysis by gas chromatography did not completely separate the diastereomeric products. When five equivalents of cesium fluoride were used, the reactions were followed by TLC analysis and quenched when the starting material was consumed. After workup and purifi-

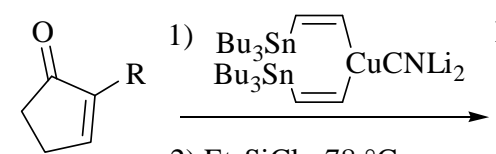

2) $\mathrm{Et}_{3} \mathrm{SiCl},-78^{\circ} \mathrm{C}$

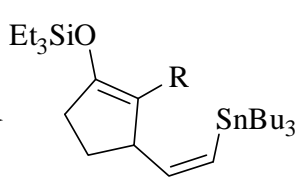

$11 \mathrm{R}=\mathrm{H} \quad 85 \%$ $13 \mathrm{R}=\mathrm{Me} 80 \%$
$10 \mathrm{R}=\mathrm{H}$
$\mathrm{R}=\mathrm{Me}$

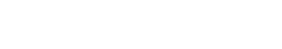

cation by silica gel chromatography, the isolated yields of each product were determined.

Treatment of $\mathbf{6}$ with five equivalents of cesium fluoride in acetonitrile at $65{ }^{\circ} \mathrm{C}$ for three hours resulted in the formation four products (Scheme 5). An inseparable mixture of two hydrindenone products, 20 and 21, were obtained in a $44 \%$ yield in a 2.3:1 ratio, as determined by ${ }^{1} \mathrm{H}-\mathrm{NMR}$, respectively ${ }^{9}$. There were two remaining side products isolated from the crude reaction mixture, the first of these side products, 22, was isolated in a $4 \%$ yield, and the second, 23, was isolated in a $10 \%$ yield. The formation of these products resulted from the isomerization of the ester enolate to the thermodynamically more stable ketone enolate. Cyclization of the ketone enolate onto the vinyl sulfone of the side chain resulted in the formation of two stereoisomeric sulfone anions $\mathbf{A}$ and $\mathbf{B}$. In the case of the syn anion $\mathbf{B}$, the anion intramoleculary condenses onto the ester carbonyl, resulting in the formation of tricyclic product 23 (Scheme 5).

Treatment of silyloxycyclopropane 6 with one equivalent of anhydrous cesium fluoride in acetonitrile at $65^{\circ} \mathrm{C}$ proceeded over a nine hour period. Aliquots of the reaction mixture were withdrawn at $30 \mathrm{~min}, 1 \mathrm{~h}, 2 \mathrm{~h}, 4 \mathrm{~h}, 6 \mathrm{~h}$, and 9 h. ${ }^{1} \mathrm{H}-\mathrm{NMR}$ analysis of these aliquots showed the formation of the same four products as described above. Compounds 21 and 22 were visible in the ${ }^{1} \mathrm{H}-\mathrm{NMR}$ spectrum after 30 min. Compounds $\mathbf{2 0}$ and $\mathbf{2 3}$ were observed in the aliquot removed at one hour. At the completion of the reaction, the ratio of bicyclo[4.3.0]nonene products $(\mathbf{2 0}: \mathbf{2 1})$ was 1:1.6. Apparently there was a change in selectivity as the equivalents of cesium fluoride was increased, as in the five equiva-
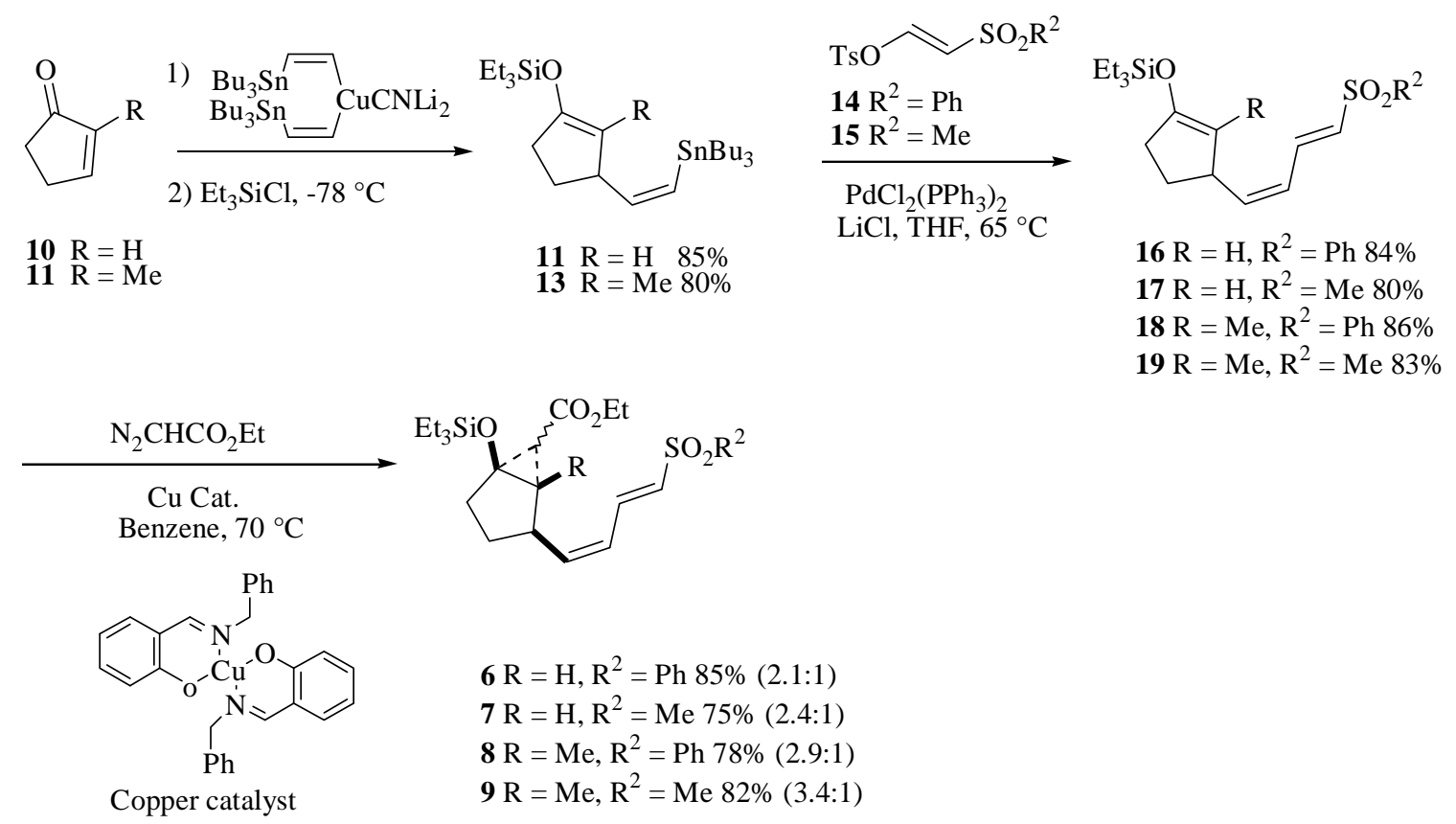

Scheme 4. 


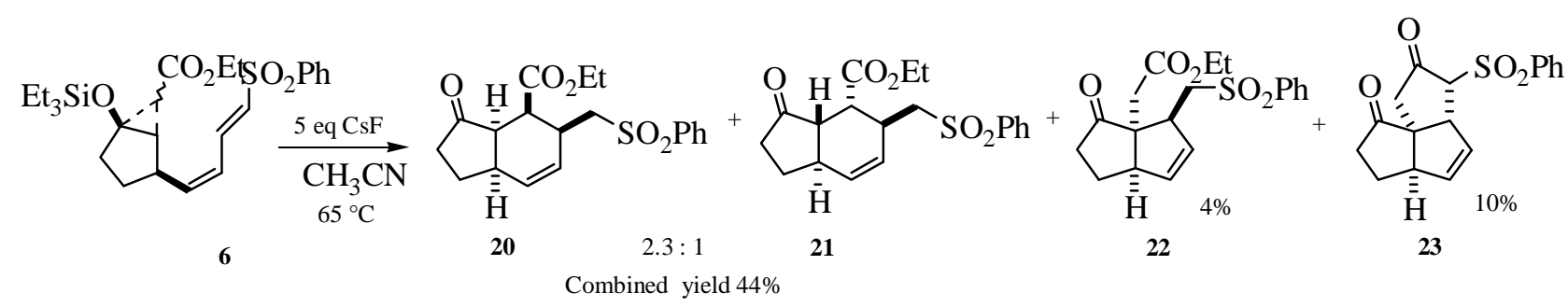

Scheme 5.

lents case compounds $\mathbf{2 0}$ and $\mathbf{2 1}$ were isolated in a 2.3:1 ratio favoring $\mathbf{2 0}$.

In a similar fashion, 7 was treated with five equivalents of cesium fluoride in acetonitrile at $65^{\circ} \mathrm{C}$ (Scheme 6). Four products (26-29) were again isolated from the crude reaction mixture. Side product $\mathbf{2 8}$, analogous to compound 22, was obtained in a $6 \%$ yield. Side product $\mathbf{2 9}$, obtained in a $12 \%$ yield, was the tricyclic compound similar to 23. Two bicyclo[4.3.0]nonene products (26, 27) were isolated in a $26 \%$ and $32 \%$ yield respectively. The assignment of the relative stereochemistry of $\mathbf{2 6}$ and 27 was accomplished using data obtained from homonuclear decoupling experiments and from two dimensional NOESY experiments.
Examination of the coupling constants for $\mathbf{2 6}$ and $\mathbf{2 7}$ showed very little variation for both compounds (Scheme 7). Because both compounds exhibit a $\mathrm{J}_{\mathrm{ad}}$ coupling constant of $8 \mathrm{~Hz}$, it was evident that each possessed a cis -ring fusion. Due to the ambiguity of the remaining coupling constants about the six-membered ring, it was impossible to assign the relative stereochemistry of the remaining stereocenters solely on the basis of the coupling constant data. We believed that $\mathbf{2 6}$ and $\mathbf{2 7}$ were isomeric at the carboxylate center $^{10}$, but we could not assign the stereochemistry with certainty. To assist in this assignment, we obtained a two dimensional NOESY spectra for each compound.

The interpretation of the NOESY spectrum for $\mathbf{2 6}$ was straightforward (Scheme 7). Compound 26 exhibited nOe

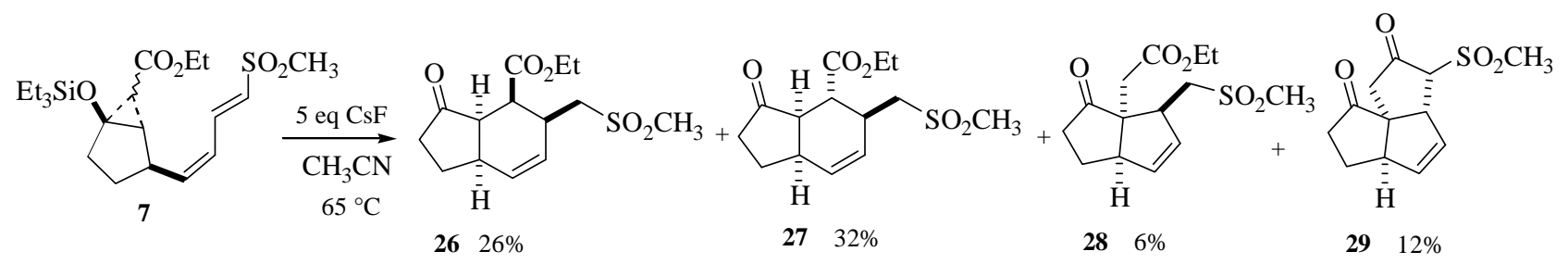

Scheme 6.<smiles>CCOC(=O)C1(COC(C)=O)C=CC2CCC(=O)C21</smiles>

26

$\mathrm{J}_{\mathrm{ac}}=4.4 \mathrm{~Hz}$

$\mathrm{J}_{\mathrm{bc}}=5.7 \mathrm{~Hz}$

$\mathrm{J}_{\mathrm{ad}}=8.1 \mathrm{~Hz}$

NOESY Data:

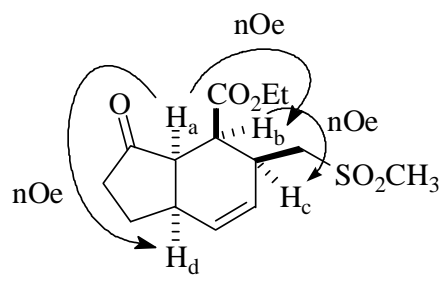

26<smiles>CCO[R5](=O)C[C@H]1C=C[C@H]2CCC(=O)[C@H]2[C@H]1C(=O)OC</smiles>

27

$\mathrm{J}_{\mathrm{ab}}=5.3 \mathrm{~Hz}$

$\mathrm{J}_{\mathrm{bc}}=4.3 \mathrm{~Hz}$

$\mathrm{J}_{\mathrm{ad}}=7.9 \mathrm{~Hz}$

Scheme 7.

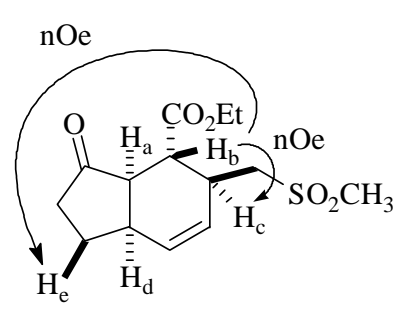

27 


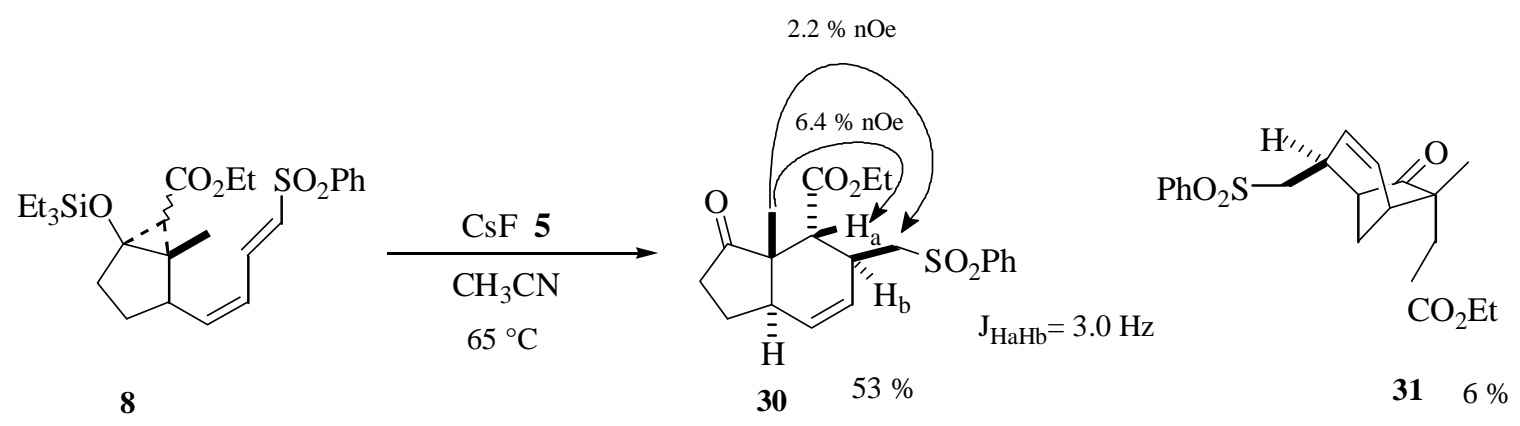

Scheme 8.

crosspeaks between $\mathrm{H}_{\mathrm{a}}$ and $\mathrm{H}_{\mathrm{b}}, \mathrm{H}_{\mathrm{a}}$ and $\mathrm{H}_{\mathrm{c}}$, and $\mathrm{H}_{\mathrm{c}}$ and $\mathrm{H}_{\mathrm{d}}$, indicating that these protons were on the same face of the molecule. Additionally, there was a crosspeak observed between $\mathrm{H}_{\mathrm{b}}$ and $\mathrm{H}_{\mathrm{d}}$, and no nOe crosspeaks observed between the the methylene protons adjacent to the sulfone and either $\mathrm{H}_{\mathrm{a}}$ or $\mathrm{H}_{\mathrm{b}}$, further proof for the stereochemical assignment. On this basis, we were confident that we correctly assigned the relative stereochemistry for $\mathbf{2 6}$.

The interpretation of the data for 27 was somewhat more complicated. The NOESY spectrum exhibited nOe crosspeaks between $\mathrm{H}_{\mathrm{b}}$ and $\mathrm{H}_{\mathrm{c}}$, suggesting that these protons may be cis as well. It was difficult to determine the presence or absence of any nOe crosspeaks between $\mathrm{H}_{\mathrm{a}}$ and $\mathrm{H}_{\mathrm{b}}$ and $\mathrm{H}_{\mathrm{a}}$ and $\mathrm{H}_{\mathrm{d}}$ due to the fact that these protons exhibit small differences in chemical shifts. In the NOESY spectrum, any nOe crosspeaks between these protons would be close to the diagonal, and without performing any computer optimizations on the spectrum, the diagonal was quite broad and noisy. Despite this problem, we were able to assign a long range nOe between $\mathrm{H}_{\mathrm{b}}$ and $\mathrm{H}_{\mathrm{e}}$, and from this crosspeak, we based our stereochemical assignment. This crosspeak was not present in the spectrum for $\mathbf{2 6}$.

The cyclization of 7 with one equivalent of cesium fluoride proceeded over a $12 \mathrm{~h}$ period. Again, aliquots were withdrawn at regular intervals, submitted to an aqueous workup and analyzed by ${ }^{1} \mathrm{H}-\mathrm{NMR}$. In this case, product formation was visible after $4 \mathrm{~h}$, at which time each product was observed. At the completion of the reaction, the crude mixture showed the ratio of 26:27 was 1:1.4, showing very little change from the 1.2:1 ratio of the five equivalent case.

Having completed the cyclizations of $\mathbf{6}$ and 7, the next step was to examine the cyclizations of the methyl substituted cyclopropanes, $\mathbf{8}$ and $\mathbf{9}$.

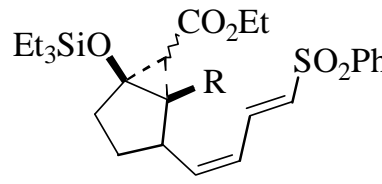

8
When $\mathbf{8}$ was treated with five equivalents of cesium fluoride two products were isolated (Scheme 8). The major product, obtained in a $53 \%$ yield, was the bicyclo[4.3.0]nonene compound 30, accompanied by a $6 \%$ yield of the bicyclo[3.2.1] octene compound 31. The unique bicyclo[3.2.1] octene structure most-likely resulted from an intermolecular equilibration of the ester enolate to the more stable ketone enolate, followed by the closure of the ketone enolate onto the side chain. Proof of the relative stereochemistry of $\mathbf{3 0}$ was obtained with the aid of a difference nuclear Overhauser enhancement experiment (Scheme 8). Irradiation of the angular methyl group produced a $2.2 \%$ enhancement of the signal corresponding to the methylene protons of the sulfone side chain, indicating that these two groups were on the same face of the molecule. Although the magnitude of the enhancement was small, we thought it was significant, particularly since the distance between these nuclei was probably greater than that often examined by nOe. More importantly, however, a $6.4 \%$ enhancement of the signal corresponding to the proton adjacent to the ester group was observed, proof that the ester group was trans to both the angular methyl group and the methylene sulfone side chain.

Analysis of the samples removed over a $12 \mathrm{~h}$ period during the treatment of $\mathbf{8}$ with one equivalent of cesium fluoride, showed a significantly different behavior than that observed for $\mathbf{5}$ and 7. At $30 \mathrm{~min}$, formation of 32, which results from the quenching of the $\gamma$-oxo- $\alpha$-ester enolate, and the bicyclo[4.3.0]nonene 30 were observed (Scheme 9). At $4 \mathrm{~h}$, the side product $\mathbf{3 1}$ was observed with the appearance of the characteristic vinyl protons. At $6 \mathrm{~h}$, the starting material was completely consumed. At this point, 32 and 30 were present in a 1:1 ratio. After $12 \mathrm{~h}$, the reaction was

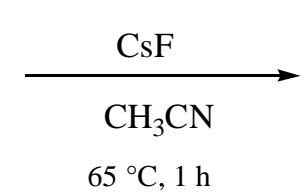

$65^{\circ} \mathrm{C}, 1 \mathrm{~h}$

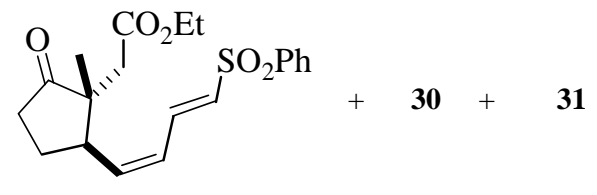

32

1:1 ratio between $\mathbf{3 2}$ and $\mathbf{3 0}$

Scheme 9. 


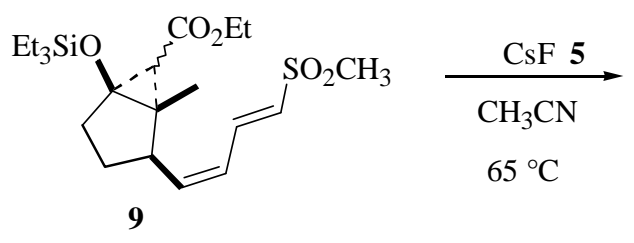

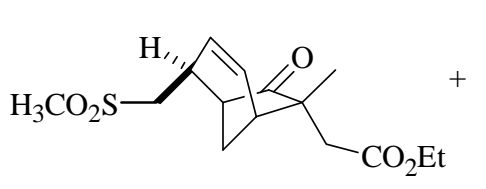

33

Combined Yield 52\% (1:1)

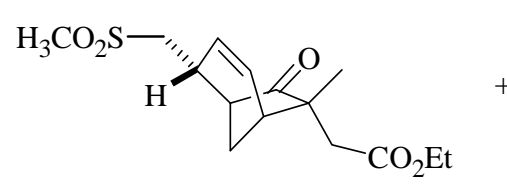

34

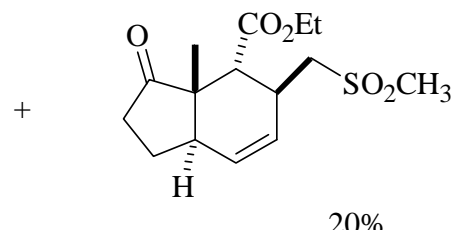

35

\section{Scheme 10.}

quenched and, after ${ }^{1} \mathrm{H}-\mathrm{NMR}$ analysis, the ratios had not changed (32:30:31 were 1:1:0.2).

Lastly, treatment of 9 with five equivalents of fluoride provided three products as shown below (Scheme 10). In this case the major product, isolated in a $52 \%$ yield, was a 1:1 mixture of bicylo[3.2.1] octenes $\mathbf{3 3}$ and 34, which were later separated by repeating the chromatographic separation. Compound $\mathbf{3 3}$ was identical in all respects to compound 31, isolated previously. Compound 34 exhibited a downfield shift of the absorptions corresponding to the methylene protons adjacent to the methyl sulfone. We attributed this shift to be due to a shielding effect by the carbonyl group. The minor compound from this reaction was the desired bicyclo[4.3.0]nonene product 35, isolated in a $20 \%$ yield. The coupling constant of the proton adjacent to the ester group was $2.7 \mathrm{~Hz}$, very similar to that obtained with 30. The relative stereochemistry of $\mathbf{3 5}$ was determined by an X-ray crystal structure.

When 9 was treated with one equivalent of cesium fluoride, four products were observed in the ${ }^{1} \mathrm{H}-\mathrm{NMR}$ spectrum. In the sample removed after $30 \mathrm{~min}$, compound 36, resulting from the quenched $\gamma$-oxo- $\alpha$-ester enolate, was observed (Scheme 11). After one hour, compounds 33, 34, and 35 were observed. At the completion of the reaction, the bridged tricyclic compounds $(33,34)$ and the bicyclo[4.3.0]nonene product $\mathbf{3 5}$ were present in a 1:1 ratio, and the non-cyclized compound $\mathbf{3 6}$ was present in minor amounts.

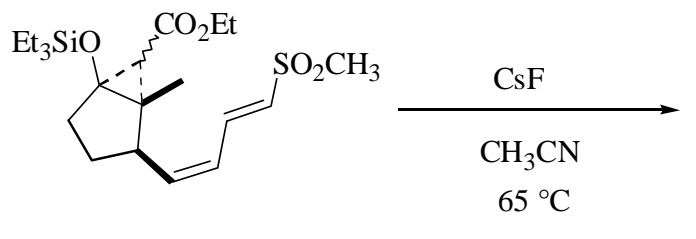

\section{Experimental}

\section{General procedure for the preparation of} bis(cis-Tri-n-butylstannyl-vinyl)cuprate

A solution of diisopropylamine $(2.4 \mathrm{mmol})$ in dry THF $(5 \mathrm{~mL})$ in a dried 3-neck round bottom flask, equipped with a solid addition tube containing cuprous cyanide and a closed pasteur pipette, was cooled to $-20{ }^{\circ} \mathrm{C}$. $n$-Butyllithium (2.4 mmol) was added and the solution was stirred for $30 \mathrm{~min}$. Tributyltin hydride ${ }^{11}(2.4 \mathrm{mmol})$ was added via syringe. This solution was stirred for $30 \mathrm{~min}$, and then cuprous cyanide $(1.2 \mathrm{mmol})$ was added via the solid addition tube. The resulting solution was stirred for $1 \mathrm{~h}$ at $-20^{\circ} \mathrm{C}$. The nitrogen supply was removed, and the acetylene apparatus was connected. Acetylene $(2.7 \mathrm{mmol}, 61 \mathrm{~mL})$ was added via a pasteur pipette whose tip was immersed beneath the surface of the solution. After completion of the acetylene addition, the reaction mixture was stirred at $-20{ }^{\circ} \mathrm{C}$ for $30 \mathrm{~min}$. The reaction mixture was cooled to $-78^{\circ} \mathrm{C}$ using a dry ice/acetone bath, and the enone $(1.0 \mathrm{mmol})$ was added rapidly via syringe. The nitrogen supply was then reattached, and the solution was allowed to warm to $-65^{\circ} \mathrm{C}$ over $45 \mathrm{~min}$. After cooling to $-78{ }^{\circ} \mathrm{C}$, triethylsilyl chloride ( $2.0 \mathrm{mmol})$ was added dropwise via syringe. The reaction mixture was allowed to warm to $-50{ }^{\circ} \mathrm{C}$ slowly, then it was poured into a rapidly stirring ice cold mixture of diethyl ether $(15 \mathrm{~mL})$, saturated aqueous ammonium chloride solution $(10 \mathrm{~mL})$, and ammonium hydroxide $(2.7 \mathrm{~mL})$. After stirring for $20 \mathrm{~min}$, the mixture was placed in a separatory funnel, and the phases were allowed to separate. The or-

Scheme 11.

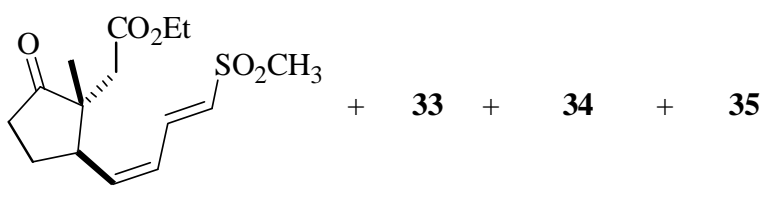


ganic phase was washed with saturated aqueous ammonium chloride:ammonium hydroxide $(4: 1)(19 \mathrm{~mL})$, distilled water $(10 \mathrm{~mL})$, and saturated aqueous sodium chloride solution $(10 \mathrm{~mL})$. The organic phase was dried with anhydrous magnesium sulfate and filtered over celite. The solvent was removed in vacuo to obtain the crude product, which was further purified using flash column chromatography on silica gel, eluting with hexane, at an elution rate of 2 inches per min, to obtain the title compound as a colorless oil.

\section{3-[(Z)-2-(Tributylstannyl)vinyl]-1-(triethylsilyloxy) cyclopent-1-ene (11)}

Prepared on a 15 mmol scale: $(6.54 \mathrm{~g}, 85 \%)$; IR (film) 807, 926, 1004, 1184, 1248, 1340, 1376, 1415, 1458, 1639, 2925, $2955 \mathrm{~cm}^{-1} ;{ }^{1} \mathrm{H}-\mathrm{NMR}\left(300 \mathrm{MHz}, \mathrm{CDCl}_{3}\right) \delta 0.70$ (q, $6 \mathrm{H}, J=8.0), 0.90(\mathrm{t}, 15 \mathrm{H}, J=7.3), 0.99(\mathrm{t}, 9 \mathrm{H}, J=8.0)$, 1.24-1.39 (m, 6H), 1.43-1.69 (m, 7H), 2.00-2.15 (m, 1H), 2.24-2.37 (m, 2H), 2.97-3.10 (m, 1H), 4.47-4.51 (m, 1H), $5.66(\mathrm{~d}, 1 \mathrm{H}, J=12.1), 6.34$ (dd, $1 \mathrm{H}, J=12.06,9.6)$; ${ }^{13} \mathrm{C}-\mathrm{NMR}\left(75.46 \mathrm{MHz}, \mathrm{CDCl}_{3}\right) \delta 4.9,6.6,10.5,13.7,27.3$, 29.0, 33.5, 50.1, 105.9, 125.5, 153.9, 156.2; HRMS (CI, $\mathrm{NH}_{3}$ ) calculated for $\mathrm{C}_{25} \mathrm{H}_{50} \mathrm{OSi}^{120} \mathrm{SnH}^{+} 515.2731$, found 515.2736 .

\section{2-Methyl-3-[(Z)-2-(tributylstannyl)vinyl]-1- (triethylsilyloxy)cyclopent-1-ene (13)}

The cuprate reagent was prepared as described above. Following the addition of the 2-methyl cyclopenten-1-one $(1.64 \mathrm{~g}, 20 \mathrm{mmol}, 1.67 \mathrm{~mL})$, the reaction mixture was warmed slowly to $-20^{\circ} \mathrm{C}$. The temperature was maintained at $-20{ }^{\circ} \mathrm{C}$ for an additional $30 \mathrm{~min}$, then cooled to $-70{ }^{\circ} \mathrm{C}$. The silyl chloride was added and the remainder of the procedure proceeded as described above. The product was obtained as a colorless oil (8.32 g, 79\%). IR (film) 875, 1016, 1087, 1379, 1416, 1460, 1592, 1685, 2852, 2925, $2956 \mathrm{~cm}^{-1}$; ${ }^{1} \mathrm{H}-\mathrm{NMR}\left(300 \mathrm{MHz}, \mathrm{CDCl}_{3}\right) \delta 0.67$ (q, 6H, $J=$ 8.0), $0.90(\mathrm{t}, 12 \mathrm{H}, J=7.2), 0.98(\mathrm{t}, 9 \mathrm{H}, J=7.9), 1.26-1.37$ $(\mathrm{m}, 7 \mathrm{H}), 1.44-1.62(\mathrm{~m}, 10 \mathrm{H}), 1.96-2.08(\mathrm{~m}, 1 \mathrm{H}), 2.25-2.34$ (m, 2H), 2.76-2.83 (m, 1H), $5.72(\mathrm{~d}, 1 \mathrm{H}, J=12.0), 6.26(\mathrm{dd}$, $1 \mathrm{H}, J=12.1,9.0) ;{ }^{13} \mathrm{C}-\mathrm{NMR}\left(75.46 \mathrm{MHz}, \mathrm{CDCl}_{3}\right) \delta 5.7$, $6.8,10.5,10.9,13.6,27.5,28.3,29.2,33.1,53.6,114.9$, 127.8, 148.0, 153.5; HRMS (CI, $\mathrm{NH}_{3}$ ) calculated for $\mathrm{C}_{26} \mathrm{H}_{52} \mathrm{OSi}^{120} \mathrm{SnH}^{+}$529.2888, found 529.2862.

\section{General procedure for the palladium-catalyzed coupling reaction}

To a stirred solution of $E$ phenylsulfonylvinyl tosylate $\mathbf{1 4}$ or Emethylsulfonylvinyl tosylate $\mathbf{1 5}$ (1.0 mmol), lithium chloride $(2.0 \mathrm{mmol})$, and bis(triphenylphosphine)palladium(II) chloride $(5 \mathrm{~mol} \%)$ in dry THF $(10 \mathrm{~mL})$ was added the appropriate vinyl stannane $(1.10 \mathrm{mmol})$ in dry THF (4 $\mathrm{mL}$ ). The addition was made by cannula and was complete with a wash of additional THF ( $2 \mathrm{~mL})$. The reaction flask was equipped with a reflux condensor and heated at $65^{\circ} \mathrm{C}$ for $24 \mathrm{~h}$. The reaction mixture was then cooled to room temperature and diluted with diethyl ether $(30 \mathrm{~mL})$. The resulting cloudy mixture was washed twice with a solution of 4:1 saturated aqueous ammonium chloride/ ammonium hydroxide $(10 \mathrm{~mL})$. The organic phase was washed with distilled water $(10 \mathrm{~mL})$ and saturated aqueous sodium chloride solution $(10 \mathrm{~mL})$ and then dried over anhydrous magnesium sulfate. After filtration over celite, the solvent was removed to obtain the crude product, which was further purified by flash column chromatography on silica gel.

\section{3-[(1Z, 3E)-4-(Phenylsulfonyl)-1,3-butadien-1-yl]-1- (triethylsilyloxy)cyclopent-1-ene (16)}

Prepared on a $3.54 \mathrm{mmol}$ scale. The crude product was purified by flash column chromatography eluting with 5:1 petroleum ether/diethyl ether to yield a colorless oil (1.28 g, 84\%). IR (film) 2956, 2876, 1743, 1637, 1584, 1447, $1408,1319,1246,1146,1086,1000,925,837 \mathrm{~cm}^{-1} ;{ }^{1} \mathrm{H}-$ NMR (300 MHz, $\left.\mathrm{CDCl}_{3}\right) \delta 0.67(\mathrm{q}, 6 \mathrm{H}, J=6.5), 0.96(\mathrm{t}$, $9 \mathrm{H}, J=6.5), 1.46-1.64(\mathrm{~m}, 1 \mathrm{H}), 2.24-2.37(\mathrm{~m}, 2 \mathrm{H}), 3.78-$ $3.90(\mathrm{~m}, 1 \mathrm{H}), 4.40-4.45(\mathrm{~m}, 1 \mathrm{H}), 5.58(\mathrm{t}, 1 \mathrm{H}, J=9.95), 5.92$ $(\mathrm{t}, 1 \mathrm{H}, J=10.9), 6.31(\mathrm{~d}, 1 \mathrm{H}, J=14.6), 7.43-7.71(\mathrm{~m}, 4 \mathrm{H})$, 7.82-7.97 (m, 2H); ${ }^{13} \mathrm{C}-\mathrm{NMR}\left(75.46 \mathrm{MHz}, \mathrm{CDCl}_{3}\right) \delta 4.9$, 6.5, 29.0, 33.2, 40.6, 103.97, 127.6, 129.2, 129.97, 133.1, 137.3, 141.3, 148.9, 157.4; HRMS (CI, $\left.\mathrm{NH}_{3}\right)$ calculated for $\mathrm{C}_{21} \mathrm{H}_{30} \mathrm{O}_{3} \mathrm{SSiH}^{+}$391.1763, found 391.1768.

\section{3-[(1Z, 3E)-4-(Methylsulfonyl)-1,3-butadienyl]-1- (triethylsilyloxy)cyclopent-1-ene (17)}

Prepared on a $5.4 \mathrm{mmol}$ scale. The crude product was purified by flash column chromatography eluting with $3: 1$ hexane/ethyl acatate to yield a pale yellow oil (1.42 g, 80\%). IR (film) 926, 966, 1004, 1411, 1460, 1586, 1639, 2877, 2955, $3012 \mathrm{~cm}^{-1} ;{ }^{1} \mathrm{H}-\mathrm{NMR}\left(300 \mathrm{MHz}, \mathrm{CDCl}_{3}\right) \delta 0.69$ $(\mathrm{q}, 6 \mathrm{H}, J=7.6), 0.98(\mathrm{t}, 9 \mathrm{H}, J=7.9), 1.53(\mathrm{~m}, 1 \mathrm{H}), 2.10-2.22$ $(\mathrm{m}, 1 \mathrm{H}), 2.31-2.36(\mathrm{~m}, 2 \mathrm{H}), 2.97(\mathrm{~s}, 3 \mathrm{H}), 3.83-3.87(\mathrm{~m}, 1 \mathrm{H})$, $4.43(\mathrm{q}, 1 \mathrm{H}, J=1.8), 5.87(\mathrm{t}, 1 \mathrm{H}, J=10.3), 5.98(\mathrm{t}, 1 \mathrm{H}, J=$ 10.9), 6.36 (d, 1H, $J=14.7), 7.58(\mathrm{dd}, 1 \mathrm{H}, J=14.7,11.4)$; ${ }^{13} \mathrm{C}-\mathrm{NMR}\left(75.46 \mathrm{MHz}, \mathrm{CDCl}_{3}\right) \delta$ 4.9, 6.4, 28.9, 33.1, 40.5, 43.2, 103.8, 121.6, 128.9, 138.2, 149.0, 157.3; HRMS (EI, $70 \mathrm{eV}$ ) calculated for $\mathrm{C}_{16} \mathrm{H}_{28} \mathrm{O}_{3} \mathrm{SSi} 328.1528$, found 328.1525 .

\section{2-Methyl-3-[(1Z, 3E)-4-(phenylsulfonyl)-1,3-butadienyl]- 1-(triethylsilyloxy)cyclopent-1-ene (18)}

Prepared on a $2.71 \mathrm{mmol}$ scale. The crude product was purified by flash column chromatography on silica gel, eluting with 5:1 petroleum ether/ diethyl ether, to obtain the title compound as a colorless oil (943.2 mg, 86\%). IR (film) 833, 962, 1017, 1086, 1146, 1208, 1243, 1328, 1446, 1628, 1683, 2876, $2956 \mathrm{~cm}^{-1}$; ${ }^{1} \mathrm{H}-\mathrm{NMR}\left(300 \mathrm{MHz}, \mathrm{CDCl}_{3}\right) \delta 0.66$ 
$(\mathrm{q}, 6 \mathrm{H}, J=8.0), 0.99(\mathrm{t}, 9 \mathrm{H}, J=7.8), 1.43(\mathrm{~s}, 3 \mathrm{H}), 1.50-1.60$ (m, 1H), 2.06-2.19 (m, 1H), 2.28-2.39 (m, 2H), 3.59-3.72 $(\mathrm{m}, 1 \mathrm{H}), 5.75(\mathrm{t}, 1 \mathrm{H}, J=10.6), 6.04(\mathrm{t}, 1 \mathrm{H}, J=11.2), 6.33$ $(\mathrm{d}, 1 \mathrm{H}, J=14.7), 7.50-7.69(\mathrm{~m}, 3 \mathrm{H}), 7.87-7.90(\mathrm{~m}, 2 \mathrm{H})$; ${ }^{13} \mathrm{C}-\mathrm{NMR}\left(75.46 \mathrm{MHz}, \mathrm{CDCl}_{3}\right) \delta 5.4,6.4,10.1,27.4,32.6$, 44.1, 113.1, 123.2, 127.4, 129.1, 130.1, 132.9, 137.1, 141.3, 147.9, 148.9; HRMS (CI, $\mathrm{NH}_{3}$ ) calculated for $\mathrm{C}_{22} \mathrm{H}_{32} \mathrm{O}_{3} \mathrm{SSiH}^{+}$405.1920, found 405.1896.

2-Methyl-3-[(1Z, 3E)-4-(methylsulfonylmethyl)-1,3butadienyl]-1-(triethylsilyloxy)cyclopent-1-ene (19)

Prepared on a $6.90 \mathrm{mmol}$ scale. The crude product was purified by flash column chromatography on silica gel, eluting with 3:1 hexane/ethyl acetate, to obtain the title compound as a pale yellow oil (1.96 g, 83\%). IR (film) 837, 965, 1007, 1133, 1208, 1244, 1307, 1381, 1411, 1459, 1632, 1684, $2955 \mathrm{~cm}^{-1}$; ${ }^{1} \mathrm{H}-\mathrm{NMR}\left(300 \mathrm{MHz}, \mathrm{CDCl}_{3}\right) \delta 0.66$ $(\mathrm{q}, 6 \mathrm{H}, J=7.9), 0.99(\mathrm{t}, 9 \mathrm{H}, J=7.9), 1.43(\mathrm{~s}, 3 \mathrm{H}), 1.52-1.61$ $(\mathrm{m}, 1 \mathrm{H}), 2.08-2.18(\mathrm{~m}, 1 \mathrm{H}), 2.31-2.38(\mathrm{~m}, 2 \mathrm{H}), 2.97(\mathrm{~s}, 3 \mathrm{H})$, $5.80(\mathrm{t}, 1 \mathrm{H}, J=10.6), 6.09(\mathrm{t}, 1 \mathrm{H}, J=11.1), 6.38(\mathrm{~d}, 1 \mathrm{H}, J$ $=14.7), 7.60(\mathrm{dd}, 1 \mathrm{H}, J=14.7,11.7) ;{ }^{13} \mathrm{C}-\mathrm{NMR}(75.46$ $\left.\mathrm{MHz}, \mathrm{CDCl}_{3}\right) \delta 5.4,6.4,10.1,27.4,32.6,43.1,44.1,113.0$, 122.9, 129.1, 138.0, 148.2, 148.8; HRMS (EI, 70eV) calculated for $\mathrm{C}_{17} \mathrm{H}_{30} \mathrm{O}_{3} \mathrm{SSi} 342.1685$, found 342.1702 .

General procedure for the copper-catalyzed cyclopropanation of the silyl enol ethers

To a stirred suspension of bis( $N$-benzylsalicylaldiminato)copper(II) $(0.006 \mathrm{mmol})$ in the appropriate silyl enol ether $(1.0 \mathrm{mmol})$ at $70{ }^{\circ} \mathrm{C}$ was added a solution of ethyl diazoacetate $(3.0 \mathrm{mmol})$ in dry benzene $(4 \mathrm{~mL})$. The addition was regulated by syringe pump and proceeded over 15 h. After the addition was complete, the reaction mixture was cooled to room temperature, and diluted with diethyl ether $(10 \mathrm{~mL})$. The resulting mixture was filtered through a short pad of silica gel, which was washed with additional diethyl ether. The solvent was removed to obtain a yellow oil, which was further purified as indicated below.

\section{Ethyl (1RS, 4RS, 5SR)-4-[(1Z, 3E)-4-(Phenylsulfonyl)- 1,3-butadien-1-yl]-1-(triethylsilyloxy)bicyclo[3.1.0] hexane-6-carboxylate (6)}

Prepared on a $3.28 \mathrm{mmol}$ scale. The crude product was purified by flash column chromatography on silica gel. eluting with 4:1 petroleum ether / diethyl ether. The product was obtained as a 2.1:1 mixture of endo:exo epimers in an overall yield of $1.3 \mathrm{~g}(85 \%)$. Analytical samples of each were obtained by repeating the chromatographic separation several times. Endo isomer: IR(film) 593, 689, 748, 835, 1087, 1147, 1447, 1633, 1727, $2957 \mathrm{~cm}^{-1} ;{ }^{1} \mathrm{H}-\mathrm{NMR}(300$ $\left.\mathrm{MHz}, \mathrm{CDCl}_{3}\right) \delta 0.61(\mathrm{q}, 6 \mathrm{H}, J=7.7), 0.91(\mathrm{t}, 9 \mathrm{H}, J=7.7)$, 1.29 (t, 3H, $J=7.1), 1.56$ (d, $1 \mathrm{H}, J=9.7), 1.60-1.80$ (m, $2 \mathrm{H}), 2.04(\mathrm{~d}, 1 \mathrm{H}, J=9.7), 2.05-2.35(\mathrm{~m}, 2 \mathrm{H}), 3.203 .35$ (m,
$1 \mathrm{H}), 4.05-4.30(\mathrm{~m}, 2 \mathrm{H}), 5.94(\mathrm{t}, 1 \mathrm{H}, J=11.1), 6.04(\mathrm{t}, 1 \mathrm{H}$, $J=10.6), 6.31(\mathrm{~d}, 1 \mathrm{H}, J=14.7), 7.45-7.65(\mathrm{~m}, 4 \mathrm{H})$, 7.80-7,95 (m, 2H); ${ }^{13} \mathrm{C}-\mathrm{NMR}\left(75.46 \mathrm{MHz}, \mathrm{CDCl}_{3}\right) \delta 5.3$, 6.6, 14.3, 31.0, 31.8, 33.0, 36.7, 37.0, 60.4, 70.95, 122.4, 127.5, 127.6, 129.2, 130.9, 133.1, 136.7, 146.9, 169.4; HRMS $\left(\mathrm{CI}, \mathrm{NH}_{3}\right)$ calculated for $\mathrm{C}_{25} \mathrm{H}_{36} \mathrm{O}_{5} \mathrm{SSiH}^{+}\left(\mathrm{MH}^{+}\right)$ 477.2131, found 477.2110. Exo isomer: $\mathrm{mp}$ : $109-110{ }^{\circ} \mathrm{C}$; IR (film) 834, 1086, 1147, 1319, 1410, 1446, 1727, 2955 $\mathrm{cm}^{-1} ;{ }^{1} \mathrm{H}-\mathrm{NMR}\left(300 \mathrm{MHz}, \mathrm{CDCl}_{3}\right) \delta 0.62$ (q, 6H, $\left.J=7.7\right)$, $0.93(\mathrm{t}, 9 \mathrm{H}, J=7.7), 1.27(\mathrm{t}, 3 \mathrm{H}, J=7.1), 1.40-1.60(\mathrm{~m}$, $1 \mathrm{H}), 1.80(\mathrm{~d}, 1 \mathrm{H}, J=3.8), 2.03(\mathrm{~d}, 1 \mathrm{H}, J=3.8), 2.10-2.29$ (m, 2H), 3.07-3.18 (m, 1H), 4.00-4.26 (m, 2H), 5.90-6.15 $(\mathrm{m}, 2 \mathrm{H}), 6.35$ (d, $1 \mathrm{H}, J=14.6), 7.47-7.66(\mathrm{~m}, 4 \mathrm{H}), 7.83-$ $7.96(\mathrm{~m}, 2 \mathrm{H}) ;{ }^{13} \mathrm{C}-\mathrm{NMR}\left(75.46 \mathrm{MHz}, \mathrm{CDCl}_{3}\right) \delta 5.7,6.7$, 14.4, 28.0, 30.0, 33.1, 36.2, 38.3, 60.4, 71.6, 123.2, 127.7, 128.3, 129.3, 131.1, 133.2, 136.44, 145.3, 169.2; HRMS (EI, 70eV) calculated for $\mathrm{C}_{25} \mathrm{H}_{36} \mathrm{O}_{5} \mathrm{SSiH}^{+} 477.2131$, found 477.2128.

Ethyl (1RS, 4RS, 5SR)-4-[(1Z, 3E)-4-(Methylsulfonyl)1,3-butadien-1-yl]-1-(triethylsilyloxy)bicyclo[3.1.0] hexane-6-carboxylate (7)

Prepared on a $3.77 \mathrm{mmol}$ scale. The crude product was further purified by flash column chromatography on silica gel, eluting with 2.8:1 hexane/ethyl acetate to yield an inseparable mixture of endo:exo epimers (ratio: 2.4:1) in an overall yield of $1.16 \mathrm{~g}(75 \%)$. The characterization described below pertains to the mixture. IR (film) 742, 819, 904, 965, 1006, 1047, 1309, 1343, 1367, 1412, 1462, 1635, 1727, 2877, $2955 \mathrm{~cm}^{-1}$; ${ }^{1} \mathrm{H}-\mathrm{NMR}\left(300 \mathrm{MHz}, \mathrm{CDCl}_{3}\right)$ spectrum of mixture includes d $0.65(\mathrm{q}, 6.1 \mathrm{H}, J=7.8), 0.96(\mathrm{t}$, $9.6 \mathrm{H}, J=8.0), 1.30(\mathrm{t}, 3.6 \mathrm{H}, J=6.9), 1.46-1.55(\mathrm{~m}, 1.1 \mathrm{H})$, $1.60(\mathrm{t}, 1.3 \mathrm{H}, J=4.8), 1.73-1.90(\mathrm{~m}, 1.2 \mathrm{H}), 2.04-2.09(\mathrm{~m}$, $1.1 \mathrm{H}), 2.13-2.20(1.4 \mathrm{H}), 2.24-2.34(\mathrm{~m}, 0.7 \mathrm{H}), 2.97(\mathrm{~s}, 3 \mathrm{H})$, 3.09-3.15 (m, 0.3H), 3.26-3.33 (m, 0.6H), 4.08-4.25 (m, $2.4 \mathrm{H}), 5.98-6.18(\mathrm{~m}, 2 \mathrm{H}), 6.39(\mathrm{~d}, 0.6 \mathrm{H}, J=14.7), 6.41(\mathrm{~d}$, $0.3 \mathrm{H}, J=14.7), 7.54(\mathrm{dd}, 1 \mathrm{H}, J=14.8,11.3) ;{ }^{13} \mathrm{C}-\mathrm{NMR}$ $\left(75.46 \mathrm{MHz}, \mathrm{CDCl}_{3}\right)$ spectrum of mixture, peaks which represent the same carbon in the two different diastereomers are grouped by parentheses d $(4.9,5.3),(6.5,6.6),(14.1$, 14.2), (27.5, 29.5), (30.4, 31.6), (32.5, 32.7), (36.3, 36.4), $(35.9,37.8), 43.1,(60.3,60.4),(70.5,71.3),(121.8,122.6)$, (129.2, 129.4), (137.8, 138.1), (145.6, 147.2), (169.2, 169.4); HRMS (EI, 70eV) calculated for $\mathrm{C}_{20} \mathrm{H}_{34} \mathrm{O}_{5} \mathrm{SSi}$ 414.1896, found 414.1877.

Ethyl (1RS, 4RS, 5SR)-5-methyl-4-[(1Z, 3E)-4(phenylsulfonyl)-1,3-butadienyl]-1-(triethylsilyloxy) bicyclo[3.1.0]hexane-6-carboxylate (8)

Prepared on a $2.92 \mathrm{mmol}$ scale. The crude product was purified by flash column chromatography on silica gel, eluting with 8:1 hexane/ethyl acetate. The product was obtained as a 2.9:1 mixture of endo:exo epimers in an 
overall yield of $1.12 \mathrm{~g}$ (78\%). A fraction containing the endo isomer was obtained for characterization purposes. The mixture of endo and exo epimers was used in subsequent reactions. IR (film) 749, 839, 963, 1004, 1049, 1086, 1147, 1212, 1321, 1414, 1448, 1633, 1726, 2877, $2956 \mathrm{~cm}^{-1}$; ${ }^{1} \mathrm{H}-\mathrm{NMR}\left(300 \mathrm{MHz}, \mathrm{CDCl}_{3}\right)$ spectrum of mixture (predominantly endo isomer) includes d $0.66(\mathrm{q}, 7.2 \mathrm{H}$, $J=8.0), 0.96(\mathrm{t}, 11.4 \mathrm{H}, J=7.8), 1.08(\mathrm{~s}, 3 \mathrm{H}), 1.21-1.28$ $(\mathrm{m}, 1 \mathrm{H}), 1.31(\mathrm{t}, 3.4 \mathrm{H}, J=7.1), 1.35-1.40(\mathrm{~m}, 1 \mathrm{H}), 1.56-$ $1.62(\mathrm{~m}, 1 \mathrm{H}), 1.63(\mathrm{~s}, 1 \mathrm{H}), 1.72(\mathrm{~s}, 0.3 \mathrm{H}), 2.11-2.19(\mathrm{~m}$, $1.4 \mathrm{H}), 2.26-2.32(\mathrm{~m}, 1 \mathrm{H}), 3.30(\mathrm{dd}, 1 \mathrm{H}, J=11.1,7.6)$, 4.10-4.21 (m, 2.5H), $5.92(\mathrm{t}, 1 \mathrm{H}, J=11.1), 6.01(\mathrm{t}, 1 \mathrm{H}, J=$ $11.1), 6.35(\mathrm{~d}, 1.2 \mathrm{H}, J=14.7), 7.50-7.65(\mathrm{~m}, 5 \mathrm{H}), 7.867 .92$ $(\mathrm{m}, 2.4 \mathrm{H}) ;{ }^{13} \mathrm{C}-\mathrm{NMR}\left(75.46 \mathrm{MHz}, \mathrm{CDCl}_{3}\right) \delta 5.4,6.7,14.3$, 15.6, 28.5, 32.0, 38.0, 38.2, 40.7, 60.4, 71.9, 123.1, 127.5, 129.1, 130.7, 133.0, 136.7, 141.1, 146.2, 169.5; HRMS (EI, $70 \mathrm{eV}$ ) calculated for $\mathrm{C}_{26} \mathrm{H}_{38} \mathrm{O}_{5} \mathrm{SSi} 490.2209$, found 490.2217 .

Ethyl (1RS, 4RS, 5SR)-5-Methyl-4-[(1Z, 3E)-4(methylsulfonyl)-1,3-butadienyl]-1-(triethylsilyloxy) bicyclo[3.1.0]hexane-6-carboxylate (9)

Prepared on a $5.66 \mathrm{mmol}$ scale. The crude product was purified by flash column chromatography on silica gel, eluting with 3:1 hexane/ethyl acetate. The product was obtained as an inseparable mixture of diastereomers in a 3.4:1 mixture of endo:exo epimers $(1.99 \mathrm{~g}, 82 \%)$. IR (film) 742, 844, 966, 1005, 1049, 1134, 1309, 1413, 1460, 1636, $1727,2879,2950 \mathrm{~cm}^{-1}$; ${ }^{1} \mathrm{H}-\mathrm{NMR}\left(300 \mathrm{MHz}, \mathrm{CDCl}_{3}\right)$ spectrum of mixture includes d 0.58-0.71 (m, 9.3H), 0.94-1.00 $(\mathrm{m}, 13.5 \mathrm{H}), 1.09(\mathrm{~s}, 3 \mathrm{H}), 1.23-1.36(\mathrm{~m}, 7 \mathrm{H}$ including EtOAc), 1.37-1.42 (m,1H), 1.52-1.61 (m, 1H), $1.63(\mathrm{~s}$, $1.1 \mathrm{H}), 1.70(\mathrm{~s}, 0.3 \mathrm{H}), 2.04$ (s, EtOAc), 2.09-2.20 (m, 1.8H), 2.27-2.33 (m, 1.1), 2.97 (s, 3H), 3.11 (dd, 0.3H, $J=11.7$, 7.2), $3.29(\mathrm{dd}, 1 \mathrm{H}, J=11.1,7.9), 4.05-4.23(\mathrm{~m}, 3.6 \mathrm{H}$ including EtOAc), 5.86-6.18 (m,3H), $6.41(\mathrm{~d}, 1.5 \mathrm{H}, J=$ 14.7), 7.57 (dd, $1.5 \mathrm{H}, J=14.6,11.4) ;{ }^{13} \mathrm{C}-\mathrm{NMR}$ (75.46 $\mathrm{MHz}, \mathrm{CDCl}_{3}$ ) spectrum of mixture, peaks which represent the same carbon in the two different diastereomers are grouped by parentheses d $(5.3,5.7),(6.6,6.7),(14.2,14.3)$, (15.5, 16.9), (26.8, 28.4), (30.5, 31.9), 33.2, 37.8, 37.9, 38.1, 40.6, (43.1, 43.4), (59.5, 60.2), (71.8, 72.3), 122.7, $123.4,124.4,129.8,137.5,137.7,145.3,146.4$, (168.4, 169.3); HRMS (EI, 70eV) calculated for $\mathrm{C}_{21} \mathrm{H}_{36} \mathrm{O}_{5} \mathrm{SSi}$ 428.2053, found 428.2048.

General procedure for the cesium fluoride induced cyclization

The silyloxycyclopropane $(1.0 \mathrm{mmol})$ was dissolved in freshly distilled acetonitrile $(20 \mathrm{~mL})$. Dry cesium fluoride $(5.0 \mathrm{mmol})$ was added and the reaction mixture was heated at $65{ }^{\circ} \mathrm{C}$ until the starting material was consumed, as observed by TLC analysis. The reaction mixture was cooled to room temperature, then concentrated in vacuo to give a dark oil. It was resuspended in ethyl acetate $(40 \mathrm{~mL})$ and washed with distilled water $(3 \times 10 \mathrm{~mL})$. The combined aqueous phases were extracted with ethyl acetate $(2 \mathrm{x}$ $10 \mathrm{~mL}$ ). The combined organic phases were washed with saturated aqueous sodium chloride solution $(15 \mathrm{~mL})$, dried with anhydrous magnesium sulfate, filtered over celite and concentrated to give a dark oil. The crude mixture was purified as described below.

Ethyl (1SR, 2SR, 3RS, 6SR)-3-(Phenylsulfonylmethyl)9-oxobicyclo[4.3.0]-non-4-ene-2-carboxylate (20) and Ethyl (1RS, 2RS, 3RS, 6SR)-3-(Phenylsulfonylmethyl)9-oxobicyclo[4.3.0]non-4-ene-2-carboxylate (21)

Prepared on a $0.79 \mathrm{mmol}$ scale. The crude product was purified by flash column chromatography on silica gel, eluting with 2:1 hexane/ethyl acetate, to give the title compounds as inseparable colorless oils ${ }^{9}$ ( $126 \mathrm{mg}, 44 \%$ 2.3:1 20 : 21). 20: IR (film) 689, 786, 929, 1033, 1087, 1146, 1238, 1371, 1400, 1448, 1585, 1731, $2987 \mathrm{~cm}^{-1}$; ${ }^{1} \mathrm{H}-\mathrm{NMR}\left(300 \mathrm{MHz}, \mathrm{CDCl}_{3}\right) \delta 1.20(\mathrm{t}, 3 \mathrm{H}, J=7.1)$, 1.75-1.90 (m, 1H), 2.052.35 (m, 3H), $2.75(\mathrm{dd}, 1 \mathrm{H}, J=7.5$, 4.6), 2.80-2.95 (m, 2H), 2.99 (dd, 1H, J=4.6, 3.2), 3.13$3.25(\mathrm{~m}, 2 \mathrm{H}), 4.08(\mathrm{q}, 2 \mathrm{H}, J=7.1), 5.66(\mathrm{dt}, 1 \mathrm{H}, J=10.1$, 2.1), 5.80 (dt, $1 \mathrm{H}, J=10.2,2.7), 7.50-7.60$ (m, 2H), 7.60$7.70(\mathrm{~m}, 1 \mathrm{H}), 7.85-7.95(\mathrm{~m}, 2 \mathrm{H}) ;{ }^{13} \mathrm{C}-\mathrm{NMR}(75.46 \mathrm{MHz}$, $\left.\mathrm{CDCl}_{3}\right) \delta 14.0,26.3,30.3,33.9,35.6,41.4,48.3,59.8,61.2$, 127.97, 128.9, 129.2, 129.8, 133.7, 139.3, 172.8, 217.8; HRMS (CI, $\mathrm{CH}_{4}$ ) calculated for $\mathrm{C}_{19} \mathrm{H}_{22} \mathrm{O}_{5} \mathrm{SH}^{+} 363.1226$, found 363.1256. 21: IR (film) 648, 689, 732, 809, 915, 1035, 1088, 1150, 1304, 1372, 1400, 1447, 1723, 2979 $\mathrm{cm}^{-1} ;{ }^{1} \mathrm{H}-\mathrm{NMR}\left(300 \mathrm{MHz}, \mathrm{CDCl}_{3}\right) \delta 1.21(\mathrm{t}, 3 \mathrm{H}, J=7.1)$, 1.80-1.95 (m, 1H), 2.10-2.35 (m, 1H), $2.90(\mathrm{dd}, 1 \mathrm{H}, J=$ $13.9,10.2), 2.95-3.20(\mathrm{~m}, 4 \mathrm{H}), 3.76(\mathrm{dd}, 1 \mathrm{H}, J=13.9,2.2)$, $4.12(\mathrm{q}, 2 \mathrm{H}, J=7.1), 5.65-5.80(\mathrm{~m}, 1 \mathrm{H}), 6.05-6.15(\mathrm{~m}, 1 \mathrm{H})$, 7.507.70 (m, 3H), 7.85-7.95 (m,2H); ${ }^{13} \mathrm{C}-\mathrm{NMR}(75.46$ $\left.\mathrm{MHz} \mathrm{CDCl}_{3}\right) \delta 14.0,26.6,30.2,36.6,36.8,41.9,47.4$, 59.2, 60.9, 127.9, 129.2, 129.7, 130.3, 133.6, 139.8, 171.0, 218.4; HRMS (CI, CH4) calculated for $\mathrm{C}_{19} \mathrm{H}_{22} \mathrm{O}_{5} \mathrm{SH}^{+}$ 363.1266 , found 363.1258 .

\section{Ethyl (1RS, 2SR, 5RS)-2-(Phenylsulfonylmethyl)-8- oxobicyclo[3.3.0]oct-3-eneacetate (22)}

Obtained as a side product during the preparation of $\mathbf{2 0}$ and 21 (11.7 mg, 4\%). IR (film) 747, 917, 1029, 1085, 1148, 1304, 1404, 1447, 1730, $2978 \mathrm{~cm}^{-1}$; ${ }^{1} \mathrm{H}-\mathrm{NMR}(360 \mathrm{MHz}$, $\left.\mathrm{CDCl}_{3}\right) \delta 1.21(\mathrm{t}, 3 \mathrm{H}, J=7.1), 1.78-1.80(\mathrm{~m}, 1 \mathrm{H}), 2.05-2.21$ $(\mathrm{m}, 2 \mathrm{H}), 2.32-2.39(\mathrm{~m}, 1 \mathrm{H}), 2.52(\mathrm{~d}, 1 \mathrm{H}, J=16.7), 2.66(\mathrm{dd}$, $1 \mathrm{H}, J=13.9,2.2), 2.85$ (d, $1 \mathrm{H}, J=16.7), 3.23$ (dqu, 1H, $J$ $=12.1,2.1), 3.37-3.39(\mathrm{~m}, 1 \mathrm{H}), 3.50(\mathrm{dd}, 1 \mathrm{H}, J=13.9,2.3)$, $4.06(\mathrm{q}, 2 \mathrm{H}, J=7.1), 5.70(\mathrm{dt}, 1 \mathrm{H}, J=5.7,2.6), 5.96(\mathrm{dt}$, $1 \mathrm{H}, J=5.7,1.9), 7.54-7.59$ (m, 2H), 7.63-7.68 (m, 1H), 7.88-7.91 (m, 2H); ${ }^{13} \mathrm{C}-\mathrm{NMR}\left(90.56 \mathrm{MHz}, \mathrm{CDCl}_{3}\right) \delta 14.1$, 
24.3, 38.0, 40.8, 48.4, 52.7, 56.4, 56.7, 60.9, 127.9, 129.4, $130.9,133.8,134.7,139.6,170.8,220.2 ; \operatorname{HRMS}\left(\mathrm{CI}, \mathrm{NH}_{3}\right)$ calculated for $\mathrm{C}_{19} \mathrm{H}_{22} \mathrm{O}_{5} \mathrm{SH}^{+} 363.1266$, found 363.1259.

(1RS, 5RS, 8RS)-4-(Phenylsulfonyl)tricyclo

[6.3.0.01,5] undec-6-ene-3,11-dione (23)

Obtained as a side product during the preparation of $\mathbf{2 0}$ and 21 (26 mg, 10\%). IR (film) 600, 688, 722, 1083, 1151, 1311, 1403, 1448, 1740, 2924, $3062 \mathrm{~cm}^{-1}$; ${ }^{1} \mathrm{H}-\mathrm{NMR}(300$ $\left.\mathrm{MHz} \mathrm{CDCl}_{3}\right) \delta 1.61\left(\mathrm{H}_{2} \mathrm{O}\right), 1.96-2.07(\mathrm{~m}, 2 \mathrm{H}), 2.29-2.37$ (m, 2H), 2.41 (d, 1H, $J=17.9), 2.90(\mathrm{~d}, 1 \mathrm{H}, J=18.0)$, $3.17-3.25(\mathrm{~m}, 1 \mathrm{H}), 3.51(\mathrm{dd}, 1 \mathrm{H}, J=6.5,1.2), 3.84(\mathrm{dd}, 1 \mathrm{H}$, $J=6.5,2.6), 5.76(\mathrm{~s}, 2 \mathrm{H}), 7.57-7.63(\mathrm{~m}, 2 \mathrm{H}), 7.68-7.74(\mathrm{~m}$, 1H), 7.87-7.90 (m, 2H); ${ }^{13} \mathrm{C}-\mathrm{NMR}\left(90.56 \mathrm{MHz}, \mathrm{CDCl}_{3}\right) \delta$ 23.7, 35.5, 46.6, 53.1, 53.9, 57.7, 75.2, 129.2, 129.3, 132.3, 134.4, 136.6, 137.2, 203.8, 218.9; HRMS (EI, 70eV) calculated for $\mathrm{C}_{17} \mathrm{H}_{16} \mathrm{O}_{4} \mathrm{SH}^{+} 316.0793$, found 316.0775 .

Ethyl (1SR, 2SR, 3RS, 6SR )-3-(Methylsulfonylmethyl)9-oxobicyclo[4.3.0]-non-4-ene-2-carboxylate (26)

Prepared on a $0.78 \mathrm{mmol}$ scale. The crude mixture was purified by flash column chromatography on silica gel, eluting with 2:1:1 diethyl ether/hexane/dichloromethane, to give the title compound as a colorless oil $(61 \mathrm{mg}, 26 \%)$. IR (film) 966, 1037, 1124, 1208, 1301, 1405, 1731, 2935 $\mathrm{cm}^{-1} ;{ }^{1} \mathrm{H}-\mathrm{NMR}\left(360 \mathrm{MHz}, \mathrm{C}_{6} \mathrm{D}_{6}\right) \delta 0.98(\mathrm{t}, 3 \mathrm{H}, J=7.1)$, 1.22-1.33 (m, 2H), 1.64-1.69 (m, 2H), 2.25-2.31 (m, 1H), 2.31 (s, 3H), $2.43(\mathrm{dd}, 1 \mathrm{H}, J=5.7,4.3), 2.59-2.66(\mathrm{~m}, 2 \mathrm{H})$, 2.97-3.02 (m, 1H), $3.81(\mathrm{dd}, 1 \mathrm{H}, J=14.1,1.6), 3.91-4.06$ $(\mathrm{m}, 2 \mathrm{H}), 5.16(\mathrm{dt}, 1 \mathrm{H}, J=10.1,1.8), 6.27$ (ddd, $1 \mathrm{H}, J=$ $10.1,4.9,2.4) ;{ }^{13} \mathrm{C}-\mathrm{NMR}\left(75.46 \mathrm{MHz}, \mathrm{CDCl}_{3}\right) \delta 14.2,26.5$, 30.2, 36.2, 37.1, 41.5, 41.7, 47.5, 58.2, 61.1, 130.0, 130.1, $171.5,218.0$; HRMS (CI, $\mathrm{NH}_{3}$ ) calculated for $\mathrm{C}_{14} \mathrm{H}_{20} \mathrm{O}_{5} \mathrm{SH}^{+} 301.1110$, found 301.1109. Decoupling experiments: Stereochemical assignments were made from a two dimensional NOESY ${ }^{1} \mathrm{H}-\mathrm{NMR}$ spectrum.

Ethyl (1SR, 2RS, 3RS, 6SR)-3-(Methylsulfonylmethyl)-9oxobicyclo[4.3.0]-non-4-ene-2-carboxylate (27)

Obtained as a co-product with 26 (74.4 mg, 32\%). IR (film) 742, 818, 966, 1033, 1139, 1181, 1237, 1301, 1372, 1404, 1463, 1730, $2928 \mathrm{~cm}^{-1} ;{ }^{1} \mathrm{H}-\mathrm{NMR}\left(360 \mathrm{MHz}, \mathrm{C}_{6} \mathrm{D}_{6}\right)$ $\delta 0.94(\mathrm{t}, 3 \mathrm{H}, J=7.1), 1.00-1.18(\mathrm{~m}, 1 \mathrm{H}), 1.29-1.41(\mathrm{~m}$, $1 \mathrm{H}), 1.64-1.79(\mathrm{~m}, 2 \mathrm{H}), 2.11(\mathrm{~s}, 3 \mathrm{H}), 2.41-2.48(\mathrm{~m}, 1 \mathrm{H})$, $2.52(\mathrm{dd}, 1 \mathrm{H}, J=14.1,7.8), 2.55-2.58(\mathrm{~m}, 1 \mathrm{H}), 2.92(\mathrm{dd}$, $1 \mathrm{H}, J=14.0,5.5), 3.06(\mathrm{dd}, 1 \mathrm{H}, J=5.3,4.3), 3.38-3.44(\mathrm{~m}$, $1 \mathrm{H}), 3.86-4.03(\mathrm{~m}, 2 \mathrm{H}), 5.26(\mathrm{dt}, 1 \mathrm{H}, J=10.2,2.5), 5.84$ (ddd, $1 \mathrm{H}, J=10.2,3.6,2.2) ;{ }^{13} \mathrm{C}-\mathrm{NMR}(90.56 \mathrm{MHz}$, $\left.\mathrm{CDCl}_{3}\right) \delta 14.1,26.4,29.7,30.2,34.1,35.7,41.6,48.5,58.6$, $61.5,128.7,130.1,173.1,218.2$; HRMS (CI, NH 3$)$ calculated for $\mathrm{C}_{14} \mathrm{H}_{20} \mathrm{O}_{5} \mathrm{SH}^{+} 301.1110$, found 301.1120. Decoupling experiments: All assignments were made from a two dimensional COSY ${ }^{1} \mathrm{H}-\mathrm{NMR}$ spectrum. Stereochemical assignments were made from a two dimensional NOESY ${ }^{1} \mathrm{H}-\mathrm{NMR}$ spectrum.

Ethyl (1RS, 2SR, 5RS)-2-(Methylsulfonylmethyl)-8oxobicyclo[3.3.0]oct-3-eneacetate (28)

Obtained as a side product during the preparation of $\mathbf{2 6}$ (13.1 mg, 6\%). IR (film) 1031, 1138, 1197, 1298, 1373, 1405, 1456, 1730, $2976 \mathrm{~cm}^{-1}$; ${ }^{1} \mathrm{H}-\mathrm{NMR}\left(300 \mathrm{MHz}, \mathrm{CDCl}_{3}\right)$ $\delta 1.24(\mathrm{t}, 3 \mathrm{H}, J=7.1), 1.761 .91(\mathrm{~m}, 1 \mathrm{H}), 2.08-2.28(\mathrm{~m}, 2 \mathrm{H})$, 2.35-2.45 (m, 1H), $2.61(\mathrm{dd}, 1 \mathrm{H}, J=13.6,12.2), 2.62(\mathrm{~d}$, $1 \mathrm{H}, J=16.4), 2.92(\mathrm{~d}, 1 \mathrm{H}, J=14.9), 2.95(\mathrm{~s}, 3 \mathrm{H}), 3.33(\mathrm{~m}$, 1H), 3.39-3.42 (m, 1H), 3.51 (dd, 1H, J = 13.6, 2.4), 4.11 $(\mathrm{q}, 2 \mathrm{H}, J=7.1), 5.72(\mathrm{dt}, 1 \mathrm{H}, J=5.8,2.6), 5.99(\mathrm{dt}, 1 \mathrm{H}, J=$ 5.7, 1.9); ${ }^{13} \mathrm{C}-\mathrm{NMR}\left(75.46 \mathrm{MHz}, \mathrm{CDCl}_{3}\right) \delta 14.2,24.3,38.0$, 40.7, 42.1, 47.9, 53.0, 55.4, 56.8, 60.9, 131.4, 134.5, 170.6, 219.6; HRMS (CI, $\mathrm{NH}_{3}$ ) calculated for $\mathrm{C}_{14} \mathrm{H}_{20} \mathrm{O}_{5} \mathrm{SH}^{+}$ 301.1110 , found 301.1105 .

(1RS, 5RS, 8RS)-4-(Methylsulfonyl) tricyclo[6.3.0.01,5]undec-6-ene-3,11-dione (29)

Obtained as a side product during the preparation of $\mathbf{2 6}$ (23 mg, 10\%). IR (film) 745, 790, 914, 964, 1086, 1136, 1306, 1404, 1457, 1649, 1741, $2930 \mathrm{~cm}^{-1}$; ${ }^{1} \mathrm{H}-\mathrm{NMR}(360$ $\left.\mathrm{MHz} \mathrm{CDCl}_{3}\right) \delta 2.01-2.08(\mathrm{~m}, 2 \mathrm{H}), 2.28-2.38(\mathrm{~m}, 2 \mathrm{H}), 2.53$ $(\mathrm{d}, 1 \mathrm{H}, J=18.4), 3.08(\mathrm{~s}, 3 \mathrm{H}), 3.11(\mathrm{~d}, 1 \mathrm{H}, J=10.5)$, 3.27-3.31 (m, 1H), 3.39 (d, $1 \mathrm{H}, J=6.8), 3.82-3.87(\mathrm{~m}, 1 \mathrm{H})$, $5.82(\mathrm{bd}, 1 \mathrm{H}, J=5.6), 5.90(\mathrm{dt}, 1 \mathrm{H}, J=5.5,2.6) ;{ }^{13} \mathrm{C}-\mathrm{NMR}$ $\left(90.56 \mathrm{MHz}, \mathrm{CDCl}_{3}\right) \delta 23.8,35.5,40.0,46.4,52.1,53.2$, 58.0, 73.8, 132.5, 136.6, 205.6, 218.8; HRMS (EI, 70eV) calculated for $\mathrm{C}_{12} \mathrm{H}_{14} \mathrm{O}_{4} \mathrm{SH}^{+} 254.0613$, found 254.0613 .

Ethyl (1RS, 2RS, 3RS, 6SR)-1-Methyl-3-

(phenylsulfonylmethyl)-9-oxo-bicyclo[4.3.0]non-4ene-2-carboxylate (30)

Prepared on a $2.29 \mathrm{mmol}$ scale. The crude mixture was purified by flash column chromatography on silica gel, eluting with 2:1 hexane/ethyl acetate, to give the title compound as a colorless oil ( $460 \mathrm{mg}, 53 \%)$. ${ }^{1} \mathrm{H}-\mathrm{NMR}(360$ $\left.\mathrm{MHz} \mathrm{CDCl}_{3}\right) \delta 0.79(\mathrm{~s}, 3 \mathrm{H}), 1.13(\mathrm{t}, 3 \mathrm{H}, J=7.1), 1.62-1.72$ (m, 1H), 2.05-2.12 (m, 1H), 2.24-2.35 (m, 1H), 2.40-2.48 (m, $1 \mathrm{H}), 2.59(\mathrm{~d}, 1 \mathrm{H}, J=3.0), 2.93-3.01(\mathrm{~m}, 2 \mathrm{H}), 3.24-3.33$ $(\mathrm{m}, 2 \mathrm{H}), 3.934 .03(\mathrm{~m}, 2 \mathrm{H}), 5.87(\mathrm{dd}, 2 \mathrm{H}, J=12.0,10.3)$, 7.54-7.58 (m, 2H), 7.63-7.68 (m, 1H), 7.90-7.92 (m, 2H); ${ }^{13} \mathrm{C}-\mathrm{NMR}\left(90.56 \mathrm{MHz}, \mathrm{CDCl}_{3}\right) \delta 13.8,16.5,22.1,33.8$, 36.6, 39.0, 49.4, 50.5, 60.7, 61.1, 127.8, 127.9, 129.2, 129.4, 133.8, 172.4, 216.0; HRMS (EI, 70eV) calculated for $\mathrm{C}_{20} \mathrm{H}_{24} \mathrm{O}_{5} \mathrm{~S}^{+} 376.1344$, found 376.1326. DNOE Data: Irradiation of the signal at $0.79 \mathrm{ppm}$ produced a $2.2 \%$ enhancement of the multiplet at $3.24-3.33 \mathrm{ppm}$, a $6.4 \%$ enhancement of the signal at $2.59 \mathrm{ppm}$, and a $5.6 \%$ enhancement of the multiplet at 1.62-1.72 ppm. 
(1SR, 2RS, 5SR, 6SR)-6-Methyl-6-(methylcarbethoxy)-2(phenylsufonyl-methyl)-7-oxobicyclo[3.2.1]oct-3ene (31)

Obtained as a side product during the preparation of $\mathbf{3 0}$ (49.6 mg, 6\%). IR (film) 689, 752, 794, 867, 1027, 1087, 1146, 1200, 1305, 1448, 1731, $2978 \mathrm{~cm}^{1} ;{ }^{1} \mathrm{H}-\mathrm{NMR}(360$ $\left.\mathrm{MHz}, \mathrm{CDCl}_{3}\right) \delta 1.13(\mathrm{~s}, 3 \mathrm{H}), 1.25(\mathrm{t}, 3 \mathrm{H}, J=7.7), 1.64$ $\left(\mathrm{H}_{2} \mathrm{O}\right), 1.85(\mathrm{~d}, 1 \mathrm{H}, J=12.5), 2.13-2.20(\mathrm{~m}, 1 \mathrm{H}), 2.23(\mathrm{~d}$, $1 \mathrm{H}, J=14.3), 2.41(\mathrm{~d}, 1 \mathrm{H}, J=14.3), 2.66-2.73(\mathrm{~m}, 1 \mathrm{H})$, 2.87-2.91 (m, 1H), 3.10-3.21 (m, 2H), $4.13(\mathrm{q}, 2 \mathrm{H}, J=7.1)$, 5.45 (ddd, $1 \mathrm{H}, J=9.6,3.6,1.2), 6.06$ (bt, $1 \mathrm{H}, J=8.1$ ), 7.58-7.63 (m, 2H), 7.65-7.72 (m, 1H), 7.90-7.97 (m, 2H); ${ }^{13} \mathrm{C}-\mathrm{NMR}\left(90.56 \mathrm{MHz}, \mathrm{CDCl}_{3}\right) \delta 14.2,18.6,26.2,36.9$, 39.6, 39.8, 48.1, 54.4, 58.9, 60.6, 126.6, 128.1, 129.5, 134.0, 135.9, 138.9, 170.3, 220.6; HRMS (CI, NH$)_{3}$ calculated for $\mathrm{C}_{20} \mathrm{H}_{24} \mathrm{O}_{5} \mathrm{SH}^{+} 377.1423$, found 377.1406. Proton decoupling: Irradiation of the signal at $6.06 \mathrm{ppm}$ affected the signal at $5.45 \mathrm{ppm}$ and the multiplet at 2.87-2.91 ppm. Irradiation of the signal at $5.45 \mathrm{ppm}$ affected the signal at $6.06 \mathrm{ppm}$ and the multiplet at $2.66-2.73 \mathrm{ppm}$. Irradiation of the multiplet at 2.87-2.91 affected the signal at $6.06 \mathrm{ppm}$ and the multiplet at $2.13-2.20 \mathrm{ppm}$. Irradiation of the multiplet at 2.80-2.85 ppm affected the multiplet at 2.66-2.73 ppm and the multiplet at $2.13-2.20 \mathrm{ppm}$. Irradiation of the multiplet at 2.66-2.73 affected the signal at $5.45 \mathrm{ppm}$, the multiplet at 3.10-3.12 ppm and the multiplet at 2.80-2.85 ppm. Irradiation of the multiplet at 2.13-2.20 ppm affected the signal at $1.85 \mathrm{ppm}$ and irradiation of the signal at 1.85 ppm affected the multiplet at 2.13-2.20 ppm.

(1SR, 2RS, 5SR, 6SR)-6-Methyl-6-(methylcarbethoxy)-2(methylsulfonylmethyl)-7-oxobicyclo[3.2.1]oct-3-ene (33)

Obtained as a side product during the preparation of $\mathbf{3 5}$ (321 mg, 34\% ). IR (film) 868, 904, 966, 1028, 1056, 1129, 1163, 1201, 1299, 1370, 1414, 1460, 1731, 2934, 2978 $\mathrm{cm}^{-1} ;{ }^{1} \mathrm{H}-\mathrm{NMR}\left(300 \mathrm{MHz}, \mathrm{CDCl}_{3}\right) \delta 1.16(\mathrm{~s}, 3 \mathrm{H}), 1.25(\mathrm{t}$, $3 \mathrm{H}, J=7.1), 1.87(\mathrm{dd}, 1 \mathrm{H}, J=12.5,0.97), 2.19-2.28$ (m, $1 \mathrm{H}), 2.26(\mathrm{~d}, 1 \mathrm{H}, J=14.3), 2.83-2.93(\mathrm{~m}, 3 \mathrm{H}), 2.95(\mathrm{~s}, 3 \mathrm{H})$, $3.11(\mathrm{~d}, 2 \mathrm{H}, J=6.8), 4.13$ (q, 2H, $J=7.1), 5.59$ (ddd, $1 \mathrm{H}$, $J=9.6,3.6,1.4), 6.11(\mathrm{~m}, 1 \mathrm{H}) ;{ }^{13} \mathrm{C}-\mathrm{NMR}(75.46 \mathrm{MHz}$, $\left.\mathrm{CDCl}_{3}\right) \delta 14.2,18.8,26.2,36.7,40.0,40.1,41.6,48.6,54.3$, $57.8,60.5,126.5,135.9,170.0,219.9 ; \mathrm{HRMS}\left(\mathrm{CI}, \mathrm{NH}_{3}\right)$ calculated for $\mathrm{C}_{15} \mathrm{H}_{22} \mathrm{O}_{5} \mathrm{SH}^{+} 315.1266$, found 315.1270 .

(1SR, 2SR, 5SR, 6SR)-6-Methyl-6-(methylcarbethoxy)2-(methylsulfonyl-methyl)-7-oxobicyclo[3.2.1]oct3-ene (34)

Obtained as a side product during the preparation of $\mathbf{3 5}$ (313 mg, 33\% ). mp: 91-92 C; IR (KBr) 740, 971, 1033, 1132, 1212, 1302, 1724, $2984 \mathrm{~cm}^{-1}$; ${ }^{1} \mathrm{H}-\mathrm{NMR}(360 \mathrm{MHz}$, $\left.\mathrm{CDCl}_{3}\right) \delta 1.13(\mathrm{~s}, 3 \mathrm{H}), 1.26(\mathrm{t}, 3 \mathrm{H}, J=7.2), 2.04(\mathrm{~d}, 1 \mathrm{H}, J$ $=12.2), 2.27(\mathrm{~d}, 1 \mathrm{H}, J=14.2), 2.35-2.42(\mathrm{~m}, 1 \mathrm{H}), 2.45(\mathrm{~d}$, $1 \mathrm{H}, J=14.2), 2.71-2.74(\mathrm{~m}, 1 \mathrm{H}), 2.83(\mathrm{dd}, 1 \mathrm{H}, J=14.1$, 7.2), 2.86-2.89 (m, 1H), 2.99 (s, 3H), 3.26 (dd, 1H, J=14.1,
6.2), 3.35-3.42 (m, 1H), $4.14(\mathrm{q}, 2 \mathrm{H}, J=7.2), 5.64(\mathrm{dd}, 1 \mathrm{H}$, $J=9.6,1.4), 6.06(\mathrm{dd}, 1 \mathrm{H}, J=8.1) ;{ }^{13} \mathrm{C}-\mathrm{NMR}(90.56 \mathrm{MHz}$, $\left.\mathrm{CDCl}_{3}\right) \delta 14.1,17.6,31.5,37.1,39.3,39.7,41.6,48.2,56.7$, 56.9, 60.6, 126.9, 134.6, 170.2, 220.6; HRMS (CI, NH N $_{3}$ calculated for $\mathrm{C}_{15} \mathrm{H}_{22} \mathrm{O}_{5} \mathrm{SH}^{+} 315.1266$, found 315.1266.

Ethyl (1RS, 2RS, 3RS, 6SR)-1-Methyl-3-

(methylsylfonylmethyl)-9-oxo-bicyclo[4.3.0]non-4-ene2-carboxylate (35)

Prepared on a $2.99 \mathrm{mmol}$ scale. The crude mixture was purified by flash column chromatography on silica gel, eluting with 3:1 diethyl ether/hexane, to give the title compound as a white solid (178.3 mg, 19\% ). An analytical sample was obtained by recrystallization from hexane/ethyl acetate. A crystal suitable for X-ray crystallographic analysis was obtained by recrystallization from ethanol. mp: 129.5-130.5 C; IR (KBr) 802, 866, 908, 977, 1021, 1071, 1139, 1214, 1254, 1304, 1465, 1713, 1730, 2903, $2976 \mathrm{~cm}^{-1} ;{ }^{1} \mathrm{H}-\mathrm{NMR}\left(360 \mathrm{MHz}, \mathrm{CDCl}_{3}\right) \delta 0.86(\mathrm{~s}$, $3 \mathrm{H}), 1.25(\mathrm{t}, 3 \mathrm{H}, J=7.1), 1.63-1.76(\mathrm{~m}, 1 \mathrm{H}), 2.10-2.17(\mathrm{~m}$, 1H), 2.31-2.54 (m, 2H), $2.77(\mathrm{~d}, 1 \mathrm{H}, J=2.3), 2.99(\mathrm{~s}, 3 \mathrm{H})$, 3.01-3.09 (m, 1H), 3.16-3.27 (m, 3H), 4.14 (q, 2H, $J=7.1)$, $5.84(\mathrm{dm}, 1 \mathrm{H}, J=9.8), 9.95(\mathrm{dm}, 1 \mathrm{H}, J=9.7) ;{ }^{13} \mathrm{C}-\mathrm{NMR}$ $\left(90.56 \mathrm{MHz}, \mathrm{CDCl}_{3}\right) \delta 13.9,16.4,22.2,33.8,36.7,38.9$, 41.2, 49.0, 50.3, 60.0, 61.1, 127.9, 129.5, 172.5, 216.0; HRMS (EI, 70eV) calculated for $\mathrm{C}_{15} \mathrm{H}_{22} \mathrm{O}_{5} \mathrm{~S} 314.1188$, found 314.1180.

\section{Acknowledgments}

F.S. and J.T.B.F. were grateful for financial support from CNPq (Brazil) during their stay at the University of Michigan.

\section{References}

1. Marino, J.P.; Long, J.K. J. Am. Chem. Soc. 1988, 110, 7916.

2. a) Burke, S.D.; Piscopio, A.D.; Buchanan, J.L. Tetrahedron Lett. 1988, 29, 2757; b) Oppolzer, W.; Dupuis, D.; Poli, G.; Raynham, T.M.; Bernardinelli, G. Tetrahedron Lett. 1988, 29, 5885; c) Sugahara, T.; Iwata, T.; Yamaoka, M.; Takano, S. Tetrahedron Lett. 1989, 30, 1821 .

3. a) Nicolaou, K.C.; Magolda, R.L. J. Org. Chem. 1981, 46, 1506; b) Roush, W.R.; Meyers, A.G. J. Org. Chem. 1981, 46, 1509; c) Edwards, M.P.; Ley, S.V.; Lister, S.G.; Tetrahedron Lett. 1981, 22, 361; d) Nicolaou, K.C.; Papahatjis, D.P.; Claremon, D. A.; Dolle, R.E., III J. Am. Chem. Soc. 1981, 103, 6967; e) Nicolaou, K.C.; Claremon, D.A.; Papahatjis, D.P.; Magolda, R.L. J. Am. Chem. Soc. 1981, 103, 6969; f) Ho, P.-T. Can. J. Chem. 1982, 60, 90; g) Roush, W.R.; Peseckis, S.M.; Walts, A.E. Tetrahedron Lett. 1982, 23, 4879; h) Edwards, M.P.; Ley, S.V.; Lister, S.G.; 
Palmer, B.D. J. Chem. Soc., Chem. Commun. 1983, 630; i) Edwards, M.P.; Ley, S.V.; Lister, S.G.; Palmer, B.D.; Williams, D.J. J. Org. Chem. 1984, 49, 3503; j) Roush, W.R.; Peseckis, S.M.; Walts, A.E. J. Org. Chem. 1984, 49, 3429; k) Nicolaou, K.C.; Papahatjis, D.P.; Claremon, D.A.; Magolda, R.L.; Dolle, R.E. J. Org. Chem. 1985, 50, 1440; l) Boeckman Jr., R.K.; Barta, T.E.J. Org. Chem. 1985, 50,3421; m) Whitney, R.A. Can. J. Chem. 1986, 64, 803; n) Burke, S.D.; Armistead, D.M.; Shankaran, K. Tetrahedron Lett. 1986, 27, 6295.

4. Marino, J.P.; Emonds, M.V.M. E. Unpublished results.

5. Marino, J.P.; Emonds, M.V.M.E.; Stengel, P.J.; Oliveira, A.R.M.; Simonelli, F.; Ferriera, J.T.B. Tetrahedron Lett. 1992, 33, 49.

6. For the analogous coupling of vinyl triflates see: a) Scott, W.J.; Crisp, G.T.; Stille, J.K. J. Am. Chem. Soc. 1984, 106, 4630; b) Scott, W.J.; Stille, J.K. J. Am. Chem. Soc. 1986, 108, 3033; c) Stille J.K.; Tanaka, M. J. Am. Chem. Soc. 1987, 109, 3785; d) Echavarren, A.M.; Stille, J.K. J. Am. Chem. Soc. 1987, 109, 5478.
7. These compounds were readily prepared by LDA deprotonation of methylphenyl sulfone of dimethyl sulfone in THF at $-20{ }^{\circ} \mathrm{C}$, followed by the addition of DMF (see: Kozerski, L. et al. Tetrahedron 1986, 42, 1469 for the analogous reaction with methylphenyl sulfoxide). Treatment of the filtered solid with 1.05 equivalents of $\mathrm{TsCl}$ in THF gave the trans-2-tosylvinyl sulfones, separable from the minor cis isomer by flash chromatography.

8. Nozaki, H.; Takaya, H.; Moriviti, S.; Noyori, R. Tetrahedron, 1968, 24, 3655.

9. Compounds $\mathbf{2 0}$ and $\mathbf{2 1}$ were eventually obtained in a pure state by Fabio Simonelli and NMR analyses were done on these samples. Unpublished results.

10 The stereochemistry of the sulfone side chain is expected to be pseudoaxial based on the A-strain model for cyclohexene systems. See: Johnson, F. Chem. Rev. 1968, 68, 375 .

11. Hayashi, K.; Iyoda, J.; Shiihara, I. J. Organometallic Chem. 1967, 10, 81. 